\title{
Twórcze orientacje życiowe studentów Studium porównawcze
}

\begin{abstract}
Abstrakt
W artykule przedstawiono główne założenia koncepcji twórczych orientacji życiowych. Opisano tę kategorię jako specyficzny, osobisty i zaangażowany sposób pełnienia codziennych obowiązków w życiu. Scharakteryzowano cechy osób preferujących twórcze orientacje życiowe. Zaprezentowano filozoficzne, psychologiczne i pedagogiczne źródła teoretyczne koncepcji oraz dotychczasowe badania twórczych orientacji życiowych wśród uczniów szkół średnich, studentów i nauczycieli. Opisano założenia metodologiczne ostatnich badań, zrealizowanych w próbie polskiej i białoruskiej młodzieży akademickiej. Przedstawiono wyniki tych badań w zakresie specyfiki socjodemograficznej obu grup, diagnozy preferencji twórczych orientacji życiowych i zależności między analizowanymi zmiennymi. Stwierdzono, że wśród badanych studentów dominują preferencje dla twórczych orientacji życiowych, ale na dość niskim poziomie akceptacji twierdzeń Skali TOŻ. Zaobserwowano istotne różnice statystyczne między grupami narodowymi pod względem wieku badanych, rocznika studiów i środowiska pochodzenia. Potwierdzono istnienie korelacji między wykształceniem matek i preferencjami twórczych orientacji życiowych polskich studentów.
\end{abstract}

Słowa kluczowe: twórcza orientacja życiowa, twórczość codzienna, student.

\section{Creative life orientations of students. Comparative study}

\begin{abstract}
In the following article the author presents the main assumptions of the concept of creative life orientations. This category is described as a specific, personal and committed way of fulfilling everyday duties in life. The characteristics of people who prefer creative life orientations were defined. The philosophical, psychological and pedagogical theoretical sources of the concept and the previous studies on creative life orientations among high school students, students and teachers were presented. The methodological assumptions of recent research, carried out in a sample of Polish
\end{abstract}

\footnotetext{
* Uniwersytet w Białymstoku.
} 
and Belorussian academic youth, were described. The results of these studies are presented in the scope of sociodemographic specifics of both groups, the diagnosis of the preferences of creative life orientations and dependencies between the analyzed variables. It was found that preferences for creative life orientations prevail among the surveyed students, but at a fairly low level of acceptance of the theorems Scale CLO. Significant statistical differences between the national groups in terms of the age of the respondents, the study year and the environment of origin were observed. The existence of a correlation between mothers' education and preferences of creative life orientations of Polish students was confirmed.

Keywords: creative life orientations, everyday creativity, student.

Autorska koncepcja twórczych orientacji życiowych jest odpowiedzią na wyzwania współczesności, która jest coraz bardziej złożona, dynamiczna i nieprzewidywalna. Jest próbą pokazania możliwości poszukiwania przez człowieka swojego zakorzenienia w bycie, swojego miejsca w społeczeństwie (po)nowoczesnym oraz kulturze zdominowanej przez media i nowoczesne technologie. W toku analiz teoretycznych oraz ich empirycznej egzemplifikacji dążę do odsłonięcia tego, co pomaga jednostce w osiągnięciu dobrostanu, pomimo trudności i zagrożeń życia. Twórczą orientację, wyrażającą się w kreatywnym myśleniu i działaniu w codziennym życiu, przedstawiam jako taki stosunek do siebie i świata, który może sprzyjać osiąganiu szczęścia.

\section{Źródła koncepcji twórczych orientacji życiowych ${ }^{1}$}

Uprawomocnienia koncepcji twórczych orientacji życiowych upatruję w czterech płaszczyznach odniesienia: 1) ontologicznej, tworzonej przez filozofię dialogu i metafizykę orientacji; 2) psychologicznej, wyrażającej się w psychologii humanistycznej, psychologii twórczości i psychologii kultury; 3) pedagogicznej, budowanej przez narrację pedagogiki twórczości i teorię emancypacyjną oraz 4) psychologiczno-pedagogicznej, której istotę stanowią teorie twórczości codziennej i koncepcja pomocy w tworzeniu.

Filozofia dialogu buduje metafizykę orientacji poszukującą sensu bycia poza teoretycznymi kategoriami, w uczestnictwie i zaangażowaniu, a jej podstawą czyni dialog (Szulakiewicz 2003: 11-27). Wyprowadzona z niej idea homo explorens „człowieka poszukującego” (Cudowska 2004: 263-268) eksponuje to, że człowiek postrzega siebie myślącego, poznającego i przekształcającego rzeczywistość, doświadcza swojej ontycznej aktywności, zdobywa świadomość swojej kreacyjnej roli, a ta umożliwia mu „umyślną twórczość”. Samoświadomość otwiera szansę na

\footnotetext{
1 Założenia koncepcji przedstawiałam już w pracach: Cudowska (2004, 2014, 2017), przywołanie ich tutaj jest niezbędne, gdyż stanowią teoretyczną podstawę badań, których wyniki prezentowane są po raz pierwszy w niniejszym artykule.
} 
zamierzone wzbogacanie siebie, a w konsekwencji na twórcze realizowanie i kreowanie własnego, niepowtarzalnego stylu życia.

Ujęcie twórczości zaproponowane przez psychologów humanistycznych Ericha Fromma (1959: 44-54), Carla R. Rogersa (1954: 249-260), Abrahama H. Maslowa (1959: 83-95), Rollo Maya (1959: 55-68), Fredericka S. Perlsa (1969), Josepha Zinkera (1977) wiąże twórczość nie tyle z wytworem, ile ze stylem życia, postrzega ją jako wartość nadającą sens ludzkiemu życiu. Twórczy potencjał jest tu przypisywany każdej jednostce, ale podkreśla się, że jego rozwój wymaga sprzyjających warunków, dlatego proces samorealizacji jest udziałem niewielu ludzi. W psychologii kultury twórczość jest zaś postrzegana jako indywidualny wybór, jako interpretacja i restrukturyzacja pojmowania świata $\mathrm{w}$ taki sposób, że wiąże się to z codziennym doświadczeniem jednostki. Analizuje się tu funkcjonowanie twórcy w określonym środowisku, uwzględniając proces tworzenia, osobowość kreatywną i wytwór (Csikszentmihalyi 1991; Kozielecki 1987, 1997, 2001, 2004).

Istotną przestrzenią wpisywania znaczeń w koncepcji twórczych orientacji życiowych jest pedagogika twórczości, której przedmiotem zainteresowań jest poszukiwanie oraz teoretyczna i empiryczna analiza edukacyjnych uwarunkowań rozwoju kreatywności dzieci, młodzieży i dorosłych (Szmidt 2013: 33). Współbrzmi z tym ujęciem koncepcja pomocy w tworzeniu Kazimierza Korniłowicza (1976) i Heleny Radlińskiej (1979), rozumiana jako budzenie oraz wspieranie zdolności twórczych ludzi w każdym wieku, co stanowi także kontekst rozumienia orientacji twórczych. Tworzenie dotyczy tu życia codziennego, rozwiązywania problemów osobistych i społecznych, podejmowania wyzwań, realizacji własnego potencjału rozwojowego, stawiania sobie realnych celów i osiągania ich poprzez aktywne, twórcze uczestnictwo w kulturze i w życiu społeczności (Szmidt 2013: 234-244). Inspiracji do rozwijania koncepcji twórczych orientacji życiowych dostarcza także nowo tworząca się subdyscyplina nauk o wychowaniu - pedagogika pozytywna (Szmidt 2013a: 13-40). Koncentruje się ona na zdrowiu, zdolnościach, talencie, mądrości, twórczości oraz innych cnotach i zasobach rozwojowych człowieka, na których trzeba budować programy wychowania. Twórczość jest tu rozumiana szeroko i egalitarnie jako aktywność i całożyciowa postawa człowieka. Takie ujęcie sprzyja także postrzeganiu twórczej orientacji życiowej jako specyficznego zasobu umożliwiającego osiąganie dobrostanu. Z kolei pedagogia agatologiczna wynikająca z filozofii Józefa Tischnera $(1993,2000)$ i Jego modelu paidei implikuje postrzeganie twórczych orientacji życiowych jako dynamicznego konstruktu kształtującego się w procesie stawania się człowieka, który rodzi się z dobra, a budowanie człowieczeństwa to wybieranie tego, co dobre. Jest to bliskie idei homo explorens, czyli istoty poszukującej zakorzenienia w bycie poprzez twórcze odczytanie i przekształcanie rzeczywistości (Cudowska 2004: 263-268). Stawanie się człowieka oznacza wydobywanie na wierzch, rozświetlanie czegoś, co jest na razie niewidoczne, ale może zostać ujawnione w procesie realizacji twórczego potencjału w imię ideałów wspólnego dobra. Perspektywa emancypacyjna (Czerepaniak-Walczak 2006) 
w oglądzie twórczych orientacji życiowych eksponuje z kolei działania podmiotu w świecie codziennym, współtworzenie procesu zmiany własnej sytuacji społecznej i historycznej oraz osiąganie nowych jakości w świecie życia przez osobiste przeżycie, odwagę dopuszczenia do głosu własnej perspektywy, przy jednoczesnym poszanowaniu i twórczym rozumieniu perspektywy Innego. Podkreśla się tu znaczenie kompetencji emancypacyjnych, czyli wyuczaną i dynamiczną sprawność podmiotu, wyrażającą się w dostrzeganiu i rozumieniu ograniczeń i deprywacji, świadomym wyrażaniu niezgody na nie, obieraniu dróg ich pokonania i osiągania nowych praw i pól wolności oraz odpowiedzialnego korzystania $\mathrm{z}$ nich $\mathrm{w}$ celu doskonalenia siebie i otoczenia. Wyrastają one z pewnej sprawności intelektualnej, która umożliwia uzasadnianie własnej perspektywy myślowej, krytyczną ocenę zdarzeń i sytuacji ograniczających oraz projektowanie działań sprzyjających osiąganiu zamierzonych celów, określanej jako racjonalność emancypacyjna.

W teoretycznej i empirycznej przestrzeni psycho-pedagogicznej szczególny wpływ na treść i sens koncepcji twórczych orientacji życiowych mają teorie twórczości codziennej (everyday creativity), egalitarnej, twórczości przez małe „t”, zaproponowane przez Ruth Richards (1999: 683-689), Marca Runco (2005: 295 -311), Annę Craft (2001: 45-61). Twórczość powszechną (egalitarną) odróżnia się od twórczości elitarnej, wybitnej. Dokonuje się ona w procesach samorealizacji jednostki, pomaga osiągnąć dobrostan psychiczny, ponieważ służy zdrowiu psychicznemu. W teoriach twórczości codziennej twórczość jest postrzegana jako własność podmiotu, powszechna, dostępna każdemu w różnym wymiarze i formie. Posiada subiektywny i osobisty charakter, jest wyrazem określonego stylu życia. Jednocześnie odnosi się do szerokiego rozumienia kultury, wykraczającego poza jej artystyczne postrzeganie. Obejmuje ona zarówno osobowość twórczą, jak i wytwory twórczości, czyli produkty, idee, zachowania, wynikające z codziennej aktywności człowieka we wszystkich sferach jego życia, od pracy zawodowej po czas wolny. Twórczość codzienna wiąże się z potrzebą rozwoju, przekształcania środowiska, przetrwania w różnych warunkach, z poszukiwaniem sensu życia, fenomenologicznym przeżywaniem i doświadczaniem codzienności. Wynika ona z realizacji zadań rozwojowych, z rozwiązywania problemów i projektowania własnej przyszłości. W tym sensie jest więc własnością człowieka i jest powszechna, jak powszechne jest uczestnictwo ludzi w kulturze, zróżnicowane jednak co do specyfiki, intensywności, charakteru, rodzaju i znaczenia. Twórczość codzienna wpisana jest w proces samorealizacji jednostki, pomaga osiągnąć dobrostan psychiczny, ponieważ sprzyja zdrowiu psychicznemu. Dzięki niej umacniają się siły fizyczne i psychiczne, twórca może stawić czoło przeciwnościom losu i rozwijać stałą tendencję do samorealizacji. Taki właśnie stosunek do życia, przejawiający się w twórczych postawach, podejmowaniu nowych zadań, oryginalnym rozwiązywaniu problemów, uznawaniu twórczości za wartość, chęci urzeczywistniania własnego potencjału rozwojowego, gotowości ciągłego uczenia się i doskonalenia w codziennym życiu jest wyrazem twórczych orientacji życiowych. Wyeksponowanie twórczości codziennej i wspar- 
cia jednostki w jej realizacji przenosi akcenty w analizie tego zjawiska, ze szczególnych uzdolnień i predyspozycji na samoświadomość jednostki. Domeną takiej twórczości są wszystkie formy i dziedziny ludzkiej aktywności, a nie tylko wybrane obszary kultury. Polega ona na generowaniu wytworów i zachowań nowych oraz wartościowych dla działającego podmiotu, zakotwiczona jest w świadomości aksjologicznej jednostki. Walor subiektywności nie umniejsza znaczenia tej aktywności dla podmiotu i społeczności, w której on funkcjonuje, pomnażając, poprzez swoją twórczą postawę, jej dobrostan.

\section{Pojęcie twórczej orientacji życiowej}

Twórcze orientacje życiowe (TOŻ) ${ }^{2}$ są specyficznym, głęboko osobistym i w pełni zaangażowanym sposobem pełnienia codziennych obowiązków w życiu. Cechuje je świadomość i celowość własnych działań, zdolność i chęć podejmowania nowych zadań, poczucie sprawstwa i kontroli wobec sytuacji zewnętrznych, podejmowanie nowych wyzwań, wypróbowywanie różnych sposobów radzenia sobie w sytuacjach trudnych, świadoma działalność na rzecz samorozwoju, wzbogacanie własnej osobowości, nabywanie nowych doświadczeń i umiejętności, poczucie wolności moralnej i autonomia sądów oceniająco-wartościujących jednostki, refleksyjność i podmiotowe zakorzenienie w bycie, odpowiedzialność za wspólne dobro.

Twórczość w tak rozumianych orientacjach ma wymiar egalitarny, demokratyczny, powszechny, jest wpisana w codzienne działania człowieka. Jest aktem podmiotowej kreacji, dzięki któremu jednostka postrzega siebie jako część większej całości, uważnie doświadcza codzienności, jest otwarta na nowe zdarzenia, postrzega otaczającą rzeczywistość z wielu różnych perspektyw. Taka twórczość umożliwia podejmowanie wysiłku kształtowania własnego życia, zapewnia refleksyjne ustosunkowanie się do reguł społecznych przyswojonych w procesie socjalizacji i świadome konfrontowanie się z własnymi lękami i słabościami (Richards 2007: 25-27). Ma ona charakter osobisty, jest wpisana w ludzką naturę, jej wyrazem jest oryginalna interpretacja codziennych doświadczeń, kierowanie się rozwagą w postępowaniu i podejmowanie intencjonalnych działań na rzecz własnego rozwoju oraz zmian $\mathrm{w}$ otoczeniu, na rzecz wspólnego dobra. W codziennej kreatywności niezbędne jest rozumienie zarówno siebie, jak i świata życia, umożliwia

\footnotetext{
2 Orientacje życiowe ujmuję jako kategorię opisową, dynamiczną, o charakterze procesualnym. Jest ona zjawiskiem złożonym zarówno w płaszczyźnie inter-, jak i intrapersonalnej, w obrębie wyborów dokonywanych przez człowieka w różnych okresach jego życia. Podstawę jej określenia stanowi ustosunkowanie się jednostki do wartości egzystencjalnych. Jest to więc względnie stały, ale też podlegający ewolucji zespół poglądów i przekonań na temat potrzeb, dążeń i celów życiowych jednostki w obszarze najbardziej cenionych przez nią wartości. Orientacja życiowa jest wypadkową wielu czynników: doświadczeń życiowych, zakresu i rodzaju wiedzy, motywacji, umiejętności działania, typu osobowościowego, stylu poznawczego, nastawień oceniająco-wartościujących, czynników środowiskowych. Orientacje życiowe rozwijają się stopniowo w miarę nabywania przez jednostkę coraz to nowych dyspozycji życiowych (Cudowska 1997: 26-40).
} 
ono dostrzeganie, nazywanie i rozwiązywanie problemów, z którymi spotykamy się każdego dnia, w różnych sytuacjach, przybliża do osiągania celów. Twórczość przez małe „t” (Craft 2001: 46-48) jest postrzegana tu jako szczególna dyspozycja osobowościowa, dzięki której jednostka kształtuje własną biografię. Jest ona też swoistym zasobem umożliwiającym codzienne wykorzystywanie swoich zalet i kompetencji. Pomysłowość, produktywność, nowatorskie podejście do różnych spraw, wnikliwość poznawcza, dociekliwość i zainteresowanie światem, które są przejawem twórczych orientacji życiowych, przyczyniają się do osiągania dobrostanu, sprzyjają realizacji dobrego życia (Modrzejewska-Świgulska 2013: 89, 99).

Twórcze orientacje życiowe są specyficzne dla danej osoby, nie ma bowiem dwóch takich samych sposobów na urzeczywistnianie osobistej kreatywności. Podstawowym imperatywem kształtowania się orientacji życiowej jest świadomość dokonywanych wyborów i podejmowanie trudu samostanowienia. Orientacje życiowe w kreatywnym wymiarze są aksjologicznie nasycone i etycznie zaangażowane. Zakorzenione są one w subiektywności, która w fenomenologicznej perspektywie poznawczej Edmunda Husserla (1967) jest źródłem wszelkiej obiektywizacji. Są także dynamiczne i procesualne, bo nie powstają w jednorazowym akcie wyłonienia się, ale wciąż przedstawiają się, kształtują się i zmieniają przez całe życie człowieka. Ze swej istoty pozostają permanentnie niedokończone, transcendentalne w sensie możliwym i transgresyjne w wymiarze koniecznym. Zawsze wiążą się z przekraczaniem ograniczeń, wyzwalaniem „od” i dążeniem „do”. Mają charakter emancypacyjny i dialogiczny, kształtują się w relacji człowieka ze światem, w procesie zdobywania podmiotowości i wolności, w dialogu z Innym.

Twórcza orientacja życiowa nie musi przejawiać się w formie wytwórczej, jej miarą nie jest wytwór, chociaż może być on jej istotnym elementem. Urzeczywistnianie twórczej orientacji życiowej staje się możliwe, gdy jednostka podda się imperatywowi działania i wyzwoli się od dotychczasowych ograniczeń, co będzie sprzyjać tworzeniu czegoś nowego. Aby mogła się ona zrealizować, trzeba dostrzec rzeczywistość w perspektywie fenomenologicznej, gdzie zwykłą rzecz przedstawia się jako fenomen. Zdolność widzenia inaczej należy bowiem do istoty twórczego podmiotu. Człowiek kreuje swoje życie wtedy, kiedy widzi jego stan aktualny, ale na tym nie poprzestaje. Dostrzega możliwości zmiany we własnym życiu, kształtowania go, a co za tym idzie podejmuje wyzwania i poddaje się imperatywowi działania. Staje więc na drodze osiągania osobistej wolności poprzez dostrzeganie tego, co jest, tego, co można zmienić i tego, co w wyniku owej zmiany może się dokonać.

Na podstawie ustaleń psychologii twórczości dotyczących specyficznych cech osób twórczych w różnych dziedzinach i zakresach, a także własnych badań i analiz w tym obszarze przypuszczam, że osoby o twórczej orientacji życiowej są lepiej przygotowane do funkcjonowania w złożonej, dynamicznej rzeczywistości, w społeczeństwie otwartym, bowiem to, co nowe i nieznane, wywołuje w nich przede wszystkim potrzebę uczenia się, poznawania i doświadczania. Charakteryzuje je autonomiczna motywacja poznawcza, w której ciekawość i pragnienie nowych 
doświadczeń ukierunkowuje działanie. Akceptują one zmianę jako coś naturalnego, aprobują różnice, potrafią harmonijnie łączyć przeciwstawne cechy. Sprawniej niż osoby o zachowawczych orientacjach spostrzegają rzeczywistość dzięki umiejętności dostrzegania konkretów, uogólniania, abstrahowania, klasyfikowania, a także świeżości spojrzenia. Można powiedzieć, że patrząc na to samo, co Inni, widzą więcej, ponieważ są bardziej wrażliwi i refleksyjni. Osoby preferujące orientacje twórcze są zdolne do pełnej koncentracji nad jakąś sprawą i przeżywania stanu zafascynowania danym problemem. Podejmują działania o różnym charakterze i zakresie, w wielu dziedzinach. Ich twórczy stosunek do życia przejawia się zarówno w działaniach incydentalnych, okazjonalnych, jak i systematycznych oraz długoterminowych. Mają silną potrzebę samorealizacji, którą zaspokajają zarówno w aktywności grupowej, w szerszym gronie, jak i w małej wspólnocie rodzinnej, ale także w samotności, w kontakcie z wewnętrznym światem swoich przeżyć. Kreatywny stosunek do życia przejawia się u nich zarówno w realizowanych codziennie zadaniach, wypełnianych obowiązkach i podejmowanych wyzwaniach, jak i w sposobie radzenia sobie z kryzysami egzystencjalnymi. Aktualizacja własnych predyspozycji, wzbogacanie samowiedzy, świadomości aksjologicznej, zdobywanie nowych umiejętności jest istotnym, choć nie jedynym wymiarem twórczej orientacji człowieka. W celowym, podmiotowym kreowaniu własnej biografii ważne miejsce zajmują także różnego rodzaju wytwory twórczej aktywności, choć nie są one warunkiem twórczej orientacji życiowej. Osoby o takiej orientacji mogą poszukiwać samospełnienia nie tylko w codziennej twórczości płynnej czy twórczości przez małe „t”, mogą także realizować się na polu twórczości skrystalizowanej, która wymaga opanowania określonej wiedzy, umiejętności, cierpliwości, odwagi i wytrwałości.

Osoby o twórczym stosunku do życia chętnie podejmują wyzwania, czasami posiadają zainteresowania artystyczne, intelektualne. Mają skłonność do poznawania i analizy zjawisk skomplikowanych, wyrażającą się chęcią zgłębienia trudnych, problematycznych zagadnień. Są zainteresowane pracą i dążeniem do sukcesu, co przejawia się motywacją do realizacji celów. Charakteryzują się determinacją i zaangażowaniem, niezależnością sądu wnioskowania, są wierne swoim poglądom. Tolerują sytuacje niejednoznaczne, co wyraża się gotowością do improwizacji, szczególnie w sytuacjach niejasnych. Wierzą we własne możliwości, chcą mieć poczucie swobody działania, są skłonne do podejmowania niekonwencjonalnych, nietypowych działań.

\section{Badania własne nad twórczymi orientacjami życiowymi}

Dotychczas zrealizowano trzy projekty badawcze obejmujące diagnozę preferencji orientacji życiowych w wymiarze twórcze-zachowawcze, w których objęto badaniami 2228 osób. Znakomitą większość próby stanowili studenci 70,3\% badanych, 
uczniowie szkół średnich reprezentowali 15,3\% próby, nauczyciele zaś stanowili $14,4 \%$ wszystkich badanych. Wyraźna przewaga młodzieży akademickiej wynika ze szczególnego charakteru tej grupy społecznej. Tworzą ją osoby o już ukształtowanych cechach osobowości, dojrzałe intelektualnie z rozwiniętą sferą aksjologicznomoralną, świadome swoich możliwości. Posiadają na ogół sprecyzowane cele, które chcą osiągnąć, określone dążenia, aspiracje i plany na bliższą oraz dalszą przyszłość. Mają zatem dość jasne preferencje w zakresie stylu życia, a jednocześnie wciąż się uczą, nabywają nowych umiejętności, podejmują różne aktywności, wzbogacają swoje doświadczenia w relacjach z Innymi. Nie bez znaczenia jest też fakt, że są chętni do udziału w badaniach, wykazują gotowość do refleksji nad swoimi postawami, wartościami, dążeniami. Z jednej strony są więc osobami dorosłymi, choć nie pełnią jeszcze wszystkich ról społecznych związanych z tym etapem życia, a z drugiej nadal podlegają różnego rodzaju wpływom, kształtującym ich umysł i wolę, rozwijających ich kompetencje poznawcze i praktyczne. Stanowią zatem grupę szczególnie ważną w procesie rozpoznawania specyfiki i uwarunkowań preferencji dla twórczych orientacji życiowych. Niezależnie bowiem od tego, w jakiej profesji będą poszukiwali swego miejsca na rynku pracy, kreatywność będzie od nich zawsze wymagana.

Pierwsze badania preferencji w zakresie twórczych orientacji życiowych przeprowadziłam w latach 2000-2002 wśród 354 studentów pedagogiki szkół wyższych w Białymstoku, Pułtusku i Ostrowcu Świętokrzyskim. Była to jednocześnie próba empirycznej weryfikacji założeń koncepcji, ukierunkowana na poszukiwanie praktycznych implikacji do jej dalszego rozwijania (Cudowska 2004: 165-193). Zaowocowało to przygotowaniem kolejnego projektu badawczego, realizowanego w latach 2006-2012 wśród 340 uczniów szkół średnich, 276 studentów i 322 nauczycieli województwa podlaskiego. Jego efektem była nie tylko diagnoza preferencji twórczych orientacji życiowych w grupach społecznie zróżnicowanych, ale także wzbogacenie narracji koncepcji twórczych orientacji życiowych o dialogiczne ujęcie tej kategorii i rozszerzenie jej interpretacji w kontekście kształtowania się tożsamości jednostki (Cudowska 2014: 42, 191). W kolejnym, trzecim projekcie zrealizowanym w latach 2014-2015 wśród 363 studentów pedagogiki UwB, obok diagnozy preferencji twórczych orientacji zweryfikowałam także hipotezę dotyczącą zależności między preferencją dla twórczej orientacji życiowej a poczuciem koherencji badanych, jako empiryczną kategorią w salutogenetycznym modelu zdrowia Aarona Antonovsky'ego (Cudowska 2017: 187-195). Niemal połowa, $48,9 \%$ badanych, charakteryzowała się wysokim wskaźnikiem poczucia koherencji, uzyskali oni bowiem wyniki wyższe od średniej w swojej grupie, zatem na kontinuum silne-słabe poczucie koherencji znaleźli się bliżej krańca oznaczającego wysoką wartość tej zmiennej. Na kontinuum twórcze-zachowawcze orientacje życiowe prawie połowa, 45,3\% badanych, usytuowała się po stronie orientacji twórczych, uzyskali oni wyniki powyżej średniej w swojej grupie, choć na niezbyt wysokim poziomie akceptacji. W efekcie analizy statystycznej potwierdzono hipotezę zakła- 
dającą istnienie związku między preferencjami dla twórczych orientacji życiowych badanych a ich poczuciem koherencji. Obie korelowane zmienne współwystępują ze sobą, silnemu poczuciu koherencji towarzyszy preferencja dla twórczej orientacji życiowej i analogicznie, słabemu poczuciu koherencji towarzyszy preferencja dla orientacji zachowawczej. Zaobserwowano silną korelację między poczuciem koherencji a preferencją dla twórczej orientacji życiowej w badanej próbie, jako uogólnionymi wyznacznikami stosunku do życia [współczynnik R Spearmana wyniósł 0,53$]$. Dodatnie wyniki analizy korelacyjnej zanotowano także w odniesieniu do związku między poszczególnymi elementami składowymi tych dwóch zmiennych. W zakresie poczucia koherencji są to: 1) poczucie zrozumiałości [PZR], 2) poczucie zaradności [PZ], 3) poczucie sensowności [PS]. Natomiast w twórczej orientacji życiowej wyróżniam cztery elementy składowe: 1) nowe sytuacje [Ns], 2) nowe wytwory [Nw], 3) elastyczność, giętkość, oryginalność myślenia [E], 4) twórczość jako wartość [Tw]. Analizy empiryczne przeprowadzone w tym zakresie umożliwiły także rozwinięcie koncepcji twórczych orientacji życiowych poprzez opisanie ich jako szczególnego zasobu, który wraz z odpowiednim poczuciem koherencji umożliwia osiągnięcie dobrostanu, czyli postrzegania swego życia jako satysfakcjonującego. Opis twórczych orientacji życiowych został więc poszerzony o ich relacje ze zdrowiem i dobrostanem człowieka. Najnowszy projekt empiryczny zrealizowano wśród studentów dwóch uczelni, polskiej i białoruskiej. W roku akademickim 2015/2016 badaniami objęto grupę 573 polskich i białoruskich studentów pedagogiki Uniwersytetu w Białymstoku i Uniwersytetu im. Aleksandra Puszkina w Brześciu. Wybrane wyniki uzyskane w toku tych eksploracji empirycznych będą przedmiotem analiz w dalszej części artykułu. Wszystkie dotychczasowe badania były prowadzone za pomocą tego samego narzędzia, autorskiej Skali Preferencji Twórczych Orientacji Życiowych, którego rzetelność i trafność została potwierdzona w toku analiz statystycznych, współczynnik Alfa-Cronbacha dla Kwestionariusza Skali Preferencji Twórczych Orientacji Życiowych wyniósł 0,86 .

\section{Metodologiczne założenia badań}

Badania preferencji twórczych orientacji życiowych polskiej i białoruskiej młodzieży akademickiej przeprowadzone na przykładzie studentów pedagogiki Uniwersytetu w Białymstoku i Państwowego Uniwersytetu im. Aleksandra Puszkina w Brześciu mieszczą się $\mathrm{w}$ paradygmacie badań triangulacyjnych. Wykorzystano analizę ilościową opisową, jedno i dwuzmiennową, a także koncepcję analizy danych jakościowych Matthew B. Milesa i A. Michaela Hubermana (2000). Podejmowane w ich toku problemy miały naturę teoretyczno-praktyczną. Były formułowane zarówno w celu wzbogacenia teoretycznej wiedzy na temat niektórych aspektów twórczych zachowań i rozumienia twórczości przez podmioty edukacji, 
które wyrażają się w ich orientacjach życiowych, jak też $\mathrm{w}$ celu wspomagania praktyki wychowania i kształcenia oraz samowychowania i samokształcenia młodzieży. Wykonano badania i analizy w dwóch oddzielnych etapach. Pierwszy mieścił się w orientacji ilościowej. Przedmiot badań definiowany był tutaj przez założenia autorskiej koncepcji twórczych orientacji życiowych, specyficzne dla niej pojęcia oraz badany za pośrednictwem Skali Preferencji Twórczych Orientacji Życiowych (TOŻ). Określono tu rozkład preferencji badanych osób w wymiarze twórcze-zachowawcze orientacje życiowe za pomocą metody sondażu diagnostycznego i techniki ankiety anonimowej oraz skalowania autorską Skalą Preferencji Twórczych Orientacji Życiowych. W konstruowaniu narzędzia zastosowano technikę polegającą na uwzględnieniu przez badacza poszczególnych aspektów mierzonego przedmiotu oraz istotnych elementów każdego z tych przedmiotów, w wyniku czego powstaje profil stanowiący podstawę formułowania określonego pytania lub twierdzenia w narzędziu. Kwestionariusz Skali Preferencji Twórczych Orientacji Życiowych obejmuje cztery aspekty a) twórczość jako wartość, b) twórczość jako wytwór, c) twórcze działanie i d) twórczą sytuację, z których każdy zawiera 12 zdań, zatem kwestionariusz zawiera 48 twierdzeń opisujących preferencje respondenta ${ }^{3}$. Na podstawie odpowiedzi określa się usytuowanie badanych na kontinuum twórcze-zachowawcze orientacje życiowe. Drugi etap sytuował się w orientacji jakościowej, a jego przedmiotem była specyfika kształcenia w obu uczelniach uwzględniająca przedmioty z zakresu psychologii i pedagogiki twórczości w planie studiów. Jego celem była charakterystyka specyfiki kształcenia w obu uczelniach w kontekście realizowania przedmiotów z zakresu psychologii i pedagogiki twórczości oraz zajęć na rzecz rozwijania twórczego myślenia i twórczych działań studentów. Poddano analizie charakter kształcenia pedagogicznego w Uniwersytecie w Białymstoku i w Uniwersytecie w Brześciu w kontekście kształtowania wśród studentów twórczych orientacji życiowych. Poszukiwano zatem odpowiedzi na szczegółowe pytania badawcze o to, w ramach jakich przedmiotów kształcenia na kierunku Pedagogika podejmowana jest problematyka twórczości i w jakim wymiarze godzinowym, jakie zagadnienia z zakresu psychologii i pedagogiki twórczości podejmowane są najczęściej w ramach zajęć na wydziałach pedagogicznych obu uniwersytetów, jakie działania, poza formalną realizacją przedmiotów zawartych w planie studiów, podejmowane są na rzecz rozwijania twórczego myślenia, twórczych zachowań i postrzegania twórczości jako wartości w codziennym życiu na tych wydziałach, oraz w jaki sposób realizowane są przedmioty z zakresu psychologii i pedagogiki twórczości na wydziałach pedagogicznych obu uniwersytetów? Do rozpoznania tej problematyki wykorzystano technikę analizy dokumentów, którą przeprowadzono w oparciu o następujące kryteria: nazwy przedmiotów z zakresu psychologii i pedagogiki twórczości w planie studiów na

\footnotetext{
3 Twierdzenia te były weryfikowane w toku badań pilotażowych i zostały poddane ocenie trafności metodą sędziów kompetentnych.
} 
obu wydziałach w Polsce i na Białorusi, ich usytuowanie w planie studiów, liczba godzin, forma realizacji, efekty realizacji, inne udokumentowane działania podejmowane na rzecz rozwijania twórczego myślenia i twórczych postaw studentów w toku studiów.

W niniejszym artykule prezentuję fragment tego projektu obejmujący wyniki badań ilościowych, diagnostycznych. W tym zakresie celem badań było: a) poznanie preferencji badanych studentów polskich i białoruskich w zakresie twórczych orientacji życiowych oraz ich uwarunkowań, a także b) porównanie preferencji w obu badanych grupach w wymiarze uogólnionego stosunku do twórczej orientacji i w aspekcie jej elementów składowych. Problem główny wyrażający się pytaniem o to, jakie są preferencje badanych studentów polskich i białoruskich w zakresie twórczych orientacji życiowych oraz jakie są ich uwarunkowania?, doprecyzowano szeregiem problemów szczegółowych, takich jak: 1) jakimi cechami socjodemograficznymi charakteryzują się badani studenci polscy i białoruscy?, 2) jaki jest stosunek badanych do nowych sytuacji, nowych wytworów?, 3) w jakim zakresie badani studenci uznają twórczość za wartość w swoim życiu?, 4) w jakim stopniu badani wykazują się elastycznością, giętkością i oryginalnością myślenia?, 5) jakie są relacje między płcią, pochodzeniem środowiskowym i wykształceniem rodziców badanych studentów polskich i białoruskich a ich uogólnionymi preferencjami dla twórczych orientacji życiowych?, 6) jakie są relacje między płcią, pochodzeniem środowiskowym i wykształceniem rodziców badanych studentów polskich i białoruskich a ich preferencjami w zakresie czterech komponentów twórczych orientacji życiowych?, 7) jakie są relacje między preferencjami w zakresie twórczych orientacji życiowych badanych studentów polskich i białoruskich? Na uogólnione preferencje dla twórczych orientacji życiowych studentów wydziałów pedagogicznych Uniwersytetu w Białymstoku i w Brześciu składają się preferencje $\mathrm{w}$ zakresie czterech komponentów twórczych orientacji życiowych: Nowe sytuacje (Ns), Nowe wytwory (Nw), Elastyczność, giętkość, oryginalność myślenia (E), Twórczość jako wartość (Tw). Ich wskaźnikiem jest liczba punktów uzyskanych w Skali Preferencji Twórczych Orientacji Życiowych w poszczególnych podskalach. Analizowano także wybrane uwarunkowania wyborów młodzieży akademickiej w zakresie orientacji życiowych w kontekście płci, wieku i pochodzenia środowiskowego badanych studentów oraz wykształcenia ich rodziców.

Wyniki badań ilościowych, zrealizowanych w pierwszym etapie projektu, poddano analizie statystycznej, w której wykorzystany został program Statistica 10.0 (StatSoft Inc., 2011). Zgodność rozpatrywanych zmiennych zależnych z rozkładem normalnym badano przy użyciu testów Huberta Lillieforsa oraz Samuela S. Shapiro i Martina Wilka, zwanego testem Shapiro-Wilka. Do weryfikacji hipotez zastosowano metody nieparametryczne, ponieważ rozkłady istotnie odbiegały od rozkładu normalnego. Do porównań między dwiema grupami wykorzystano test Henry B. Manna i Davida R. Whitneya (test U Manna-Whitneya), natomiast w sytuacji, gdy liczba porównywanych grup była większa od dwóch użyto testu Williama H. Kru- 
skala i W. Allena Wallisa (test Kruskala-Wallisa), wraz z testem post-hoc Oscara J. Dunna. Analizę korelacji przeprowadzono przy wykorzystaniu współczynnika korelacji rang Charlesa Spearmana wraz z testem istotności dla tego współczynnika i przyjęto poziom istotności $\alpha=0,05$. Za istotne statystycznie uznawano zatem wyniki, gdy wyliczone prawdopodobieństwo testowe p spełniało nierówność $\mathrm{p}<0,05$. Porównania między grupą polską a białoruską w odniesieniu do cech socjodemograficznych wykonywano testem chi-kwadrat.

\section{Cechy badanych oraz ich preferencje w zakresie orientacji życiowych}

W badaniach wzięło udział 303 studentów polskich i 270 studentów białoruskich, czyli razem 573 osoby. Grupa ta była dość jednorodna pod względem płci, ponieważ znalazło się w niej tylko 39 mężczyzn, którzy stanowili zaledwie 6,8\% badanych, 6,9\% wśród polskich studentów i 6,7\% wśród studentów białoruskich. Proporcje płci były zatem bardzo wyrównane w obu próbach, zdecydowanie dominowały kobiety, które stanowiły odpowiednio 93,1\% badanych studentów polskich i 93,3\% studentów białoruskich. Taka przewaga płci potwierdza obecną od wielu lat feminizację profesji pedagogicznych reprezentowanych przez nauczycieli, szczególnie wczesnej edukacji, i wychowawców w różnego typu placówkach oświatowych. Czyni także niezasadnym dalsze analizy relacji między płcią badanych a ich preferencjami w zakresie twórczych orientacji życiowych. Natomiast test chi-kwadrat $\chi^{2}=269,0$ przy stopniach swobody $\mathrm{df}=2 \mathrm{i}$ poziomie istotności $\mathrm{p}=0,0000$ okazał się istotny statystycznie $\mathrm{w}$ odniesieniu do wieku badanych. Wśród studentów polskich przeważają osoby w wieku 23 lat i więcej $(61,7 \%)$, w gronie białoruskich grupa podzieliła się niemal po połowie pomiędzy osoby w wieku $17-19$ lat $(50,7 \%)$ i $20-22$ lat $(45,6 \%)$. Studenci polscy są zatem zasadniczo starsi, co wynika z różnic organizacyjnych systemów szkolnych obu krajów, a także specyfiki roczników, z których rekrutowali się badani (tabela 1).

Tabela 1. Wiek badanych studentów

\begin{tabular}{|l|c|r|r|r|r|c|}
\hline \multirow{2}{*}{ Wiek } & \multicolumn{2}{|c|}{ Grupa polska } & \multicolumn{2}{c|}{ Grupa białoruska } & \multicolumn{2}{c|}{ Razem } \\
\cline { 2 - 7 } & $\mathrm{N}$ & \multicolumn{1}{c|}{$\%$} & $\mathrm{~N}$ & $\%$ & $\mathrm{~N}$ & $\%$ \\
\hline 17-19 lat & 10 & 3,3 & 137 & 50,7 & 147 & 25,7 \\
\hline 20-22 lata & 106 & 35,0 & 123 & 45,6 & 229 & 40,0 \\
\hline 23 lata i więcej & 187 & 61,7 & 10 & 3,7 & 197 & 34,4 \\
\hline Ogółem & 303 & 100,0 & 270 & 100,0 & 573 & 100,0 \\
\hline
\end{tabular}

Źródło: badania własne. 
Jednak rozkład tej zmiennej $\mathrm{w}$ całej badanej próbie wskazuje na dominację studentów w wieku 20-22 lata, choć jest ona nieznaczna w stosunku do starszej grupy i wynosi tylko 5,6 p.p. Najmniej jest natomiast w próbie badanej studentów w wieku 17-19 lat i niemal cała ta grupa pochodzi z brzeskiego uniwersytetu, $\mathrm{z}$ wydziału pedagogicznego Uniwersytetu w Białymstoku jest tyko dziesięcioro badanych. Średni wiek w grupie polskich studentów wyniósł 22,5 lat, natomiast w grupie studentów białoruskich 19,6 lat, zaś średnia wieku dla całej próby wyniosła 21,1 lat (rycina 1 ). Wynik testu chi-kwadrat, $\chi^{2}=272,3$ przy stopniach swobody $\mathrm{df}=4 \mathrm{i}$ poziomie istotności $\mathrm{p}=0,0000$, okazał się istotny statystycznie, co wskazuje

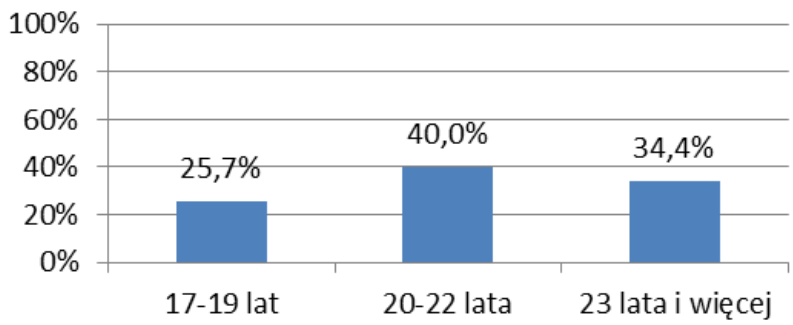

Ryc. 1. Rozkład wieku badanych studentów polskich i białoruskich Źródło: badania własne

na zależność między analizowanymi tu zmiennymi. W grupie polskiej zdecydowanie przeważali studenci pierwszego roku studiów drugiego stopnia, czyli magisterskich, stanowili oni 77,2\% badanych. Poza nimi znaleźli się tu studenci pierwszego roku studiów pierwszego stopnia, czyli licencjackich, $22,8 \%$ osób. W próbie białoruskiej byli reprezentowani studenci wszystkich roczników, najliczniejszą grupą byli studenci trzeciego roku, $24,8 \%$ badanych, zaś najmniej liczną studenci ostatniego, piątego roku studiów, 12,2\% respondentów. Takie zróżnicowanie próby jest też efektem rozciągnięcia badań $\mathrm{w}$ czasie związanego z trudnościami $\mathrm{w}$ ich realizacji, naturalnymi przy tego typu eksploracjach w dwóch różnych krajach, oraz dostępnością określonych grup. Nie jest to jednak jakoś szczególnie istotne dla diagnozy w zakresie preferencji twórczych orientacji życiowych, gdyż wcześniejsze analizy nie wskazywały na znaczące różnice $\mathrm{w}$ tym obszarze $\mathrm{w}$ grupach młodzieży w przedziale 17-23 lata (tabela 2; rycina 2).

Tabela 2. Roczniki badanych studentów

\begin{tabular}{|l|c|c|c|c|c|c|}
\hline \multirow{2}{*}{ Rok studiów } & \multicolumn{2}{|c|}{ Grupa polska } & \multicolumn{2}{c|}{ Grupa białoruska } & \multicolumn{2}{c|}{ Razem } \\
\cline { 2 - 7 } & $\mathrm{N}$ & $\%$ & $\mathrm{~N}$ & $\%$ & $\mathrm{~N}$ & $\%$ \\
\hline I rok & 69 & 22,8 & 61 & 22,6 & 130 & 22,7 \\
\hline II rok & 0 & 0,0 & 57 & 21,1 & 57 & 9,9 \\
\hline
\end{tabular}


Tab. 2 (cd.)

\begin{tabular}{|l|r|r|r|r|r|r|}
\hline III rok & 0 & 0,0 & 67 & 24,8 & 67 & 11,7 \\
\hline IV rok (Ir. IIst.) & 234 & 77,2 & 52 & 19,3 & 286 & 49,9 \\
\hline V rok (IIr. IIst.) & 0 & 0,0 & 33 & 12,2 & 33 & 5,8 \\
\hline Ogółem & 303 & 100,0 & 270 & 100,0 & 573 & 100,0 \\
\hline
\end{tabular}

Źródło: badania własne.

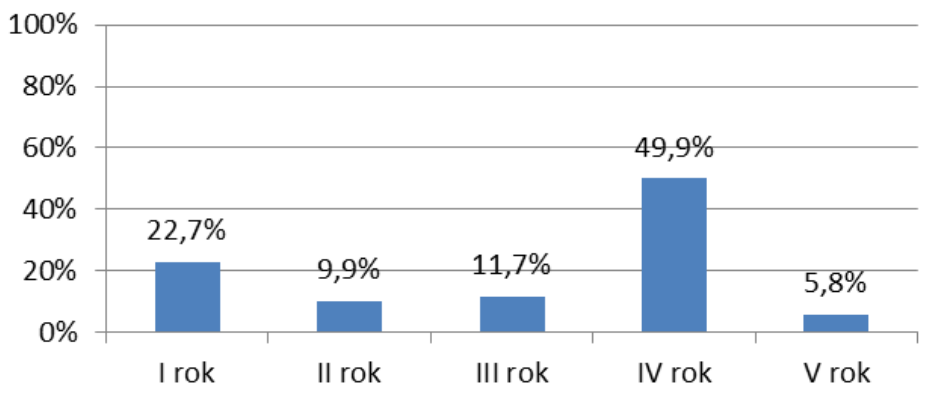

Ryc. 2. Roczniki, z których rekrutowali się badani studenci Źródło: badania własne

Badana grupa okazała się dość zróżnicowana pod względem pochodzenia środowiskowego. Dominują w niej osoby z małych miast, liczących do 20 tys. mieszkańców, stanowią one 38,6\% wszystkich badanych. Na drugim miejscu znalazła się grupa studentów z dużych miast, liczących powyżej 100 tys. mieszkańców, stanowią oni $32,1 \%$ badanych. Najmniej studentów pochodzi ze wsi, $29,3 \%$ osób, chociaż różnice między grupami nie są znaczne i wahają się $\mathrm{w}$ przedziale między 2,8 a 9,3 p.p. Nikt natomiast nie wskazał średniego miasta, liczącego od 20 do 100 tys. mieszkańców jako miejsca swojego pochodzenia, co wynika zapewne ze specyfiki terenów, na których były przeprowadzane badania (tabela 3).

Tabela 3. Środowiska, z których pochodzą badani studenci

\begin{tabular}{|l|c|c|c|c|c|c|}
\hline \multirow{2}{*}{ Pochodzenie } & \multicolumn{2}{|c|}{ Grupa polska } & \multicolumn{2}{c|}{ Grupa białoruska } & \multicolumn{2}{c|}{ Razem } \\
\cline { 2 - 7 } & $\mathrm{N}$ & $\%$ & $\mathrm{~N}$ & $\%$ & $\mathrm{~N}$ & $\%$ \\
\hline Duże miasto & 95 & 31,4 & 89 & 33,0 & 184 & 32,1 \\
\hline Małe miasto & 102 & 33,7 & 119 & 44,1 & 221 & 38,6 \\
\hline Wieś & 106 & 35,0 & 62 & 23,0 & 168 & 29,3 \\
\hline Ogółem & 303 & 100,0 & 270 & 100,0 & 573 & 100,0 \\
\hline
\end{tabular}

Źródło: badania własne. 
Wynik testu chi-kwadrat, $\chi^{2}=11,2$ przy stopniach swobody $\mathrm{df}=2 \mathrm{i}$ poziomie istotności $\mathrm{p}=0,0038$, jest istotny statystycznie, w obu grupach mamy podobny udział mieszkańców dużych miast, natomiast proporcje między małym miastem i wsią są już wyraźnie zachwiane. Wśród studentów polskich dominują, chociaż nieznacznie, osoby pochodzące ze wsi, stanowią one $35 \%$ badanych, natomiast w próbie białoruskiej takich studentów jest najmniej, 29,3\% przy wyraźnej przewadze osób pochodzących z małych miast, które stanowią 38,6\% badanych. Grupa polskich studentów jest w ogóle mniej zróżnicowana pod względem tej zmiennej niż grupa białoruska, pomiędzy studentami pochodzącymi z dużego i małego miasta oraz ze wsi zachodzą niewielkie różnice, średnio 2,2 p.p. Wśród studentów brzeskiego uniwersytetu dyferencjacje są większe i wynoszą średnio 5,9 p.p. (rycina 3).

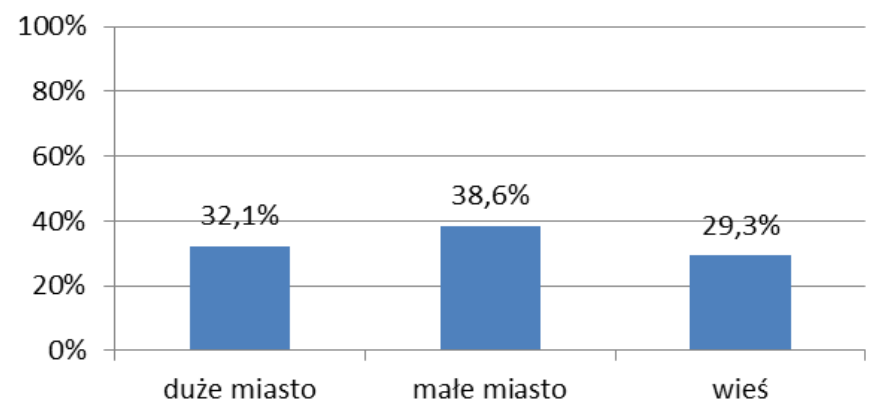

Ryc. 3. Pochodzenie środowiskowe badanych studentów Źródło: badania własne

Badana próba jest także zróżnicowana pod względem wykształcenia rodziców studentów, zarówno w wymiarze wewnątrzgrupowym, jak i pomiędzy grupami narodowymi. Zmienna ta w poprzednich badaniach okazała się ważna dla preferencji w zakresie twórczych orientacji życiowych, dlatego w tym projekcie również została poddana analizie. Wśród matek badanych studentów dominuje wykształcenie średnie drugiego stopnia, 36,5\% z nich posiada maturę. Na drugim miejscu znaleźli się studenci, których matki legitymują się wykształceniem wyższym akademickim, stanowią oni $26,2 \%$ badanych. Podobną liczebnie grupę, mniejszą tylko o 2,6 p.p., stanowią matki legitymujące się wykształceniem zasadniczym zawodowym, a więc nieposiadające matury. Zdecydowanie najmniej liczną grupą są studenci, których matki mają tylko wykształcenie podstawowe i niepełne podstawowe, stanowi ona 12,4\% wszystkich badanych (tabela 4). 
Tabela 4. Wykształcenie matek badanych studentów polskich i białoruskich

\begin{tabular}{|l|r|r|r|r|r|r|}
\hline \multirow{2}{*}{ Wykształcenie matki } & \multicolumn{2}{|c|}{ Grupa polska } & \multicolumn{2}{c|}{ Grupa białoruska } & \multicolumn{2}{c|}{ Razem } \\
\cline { 2 - 7 } & \multicolumn{1}{c|}{$\mathrm{N}$} & \multicolumn{1}{c|}{$\%$} & $\mathrm{~N}$ & \multicolumn{1}{c|}{$\%$} & $\mathrm{~N}$ & \multicolumn{1}{c|}{$\%$} \\
\hline $\begin{array}{l}\text { Niepełne podstawo- } \\
\text { we }\end{array}$ & 0 & 0,0 & 4 & 1,5 & 4 & 0,7 \\
\hline Podstawowe & 18 & 5,9 & 49 & 18,1 & 67 & 11,7 \\
\hline Zawodowe & 93 & 30,7 & 42 & 15,6 & 135 & 23,6 \\
\hline Średnie & 108 & 35,6 & 101 & 37,4 & 209 & 36,5 \\
\hline Wyższe & 82 & 27,1 & 68 & 25,2 & 150 & 26,2 \\
\hline Brak odpowiedzi & 2 & 0,7 & 6 & 2,2 & 8 & 1,4 \\
\hline Ogółem & 303 & 100,0 & 270 & 100,0 & 573 & 100,0 \\
\hline
\end{tabular}

Źródło: badania własne.

Wynik testu chi-kwadrat, $\chi^{2}=36,9$ przy stopniach swobody $\mathrm{df}=4 \mathrm{i}$ poziomie istotności $\mathrm{p}=0,0000$, wskazuje na istotne zależności między zmiennymi, a zróżnicowanie dotyczy przede wszystkim proporcji między podstawowym i zawodowym wykształceniem matek badanych studentów polskich i białoruskich. Wykształcenie matek polskich respondentów jest nieco wyższe od matek białoruskich, jednak są to nieznaczne różnice. Na poziomie wykształcenia akademickiego, 0,9\% więcej matek polskich studentów, ale na poziomie wykształcenia średniego 1,8\% więcej matek studentów białoruskich. Większe dyferencjacje pojawiają się w przypadku wykształcenia zawodowego i podstawowego. Szkołę zawodową ukończyło niemal dwa razy więcej matek polskich studentów niż białoruskich, różnica wynosi tu 15,1 p.p. Natomiast w grupie matek białoruskich studentów jest znacznie więcej, o 12,2 p.p., kobiet z wykształceniem podstawowym. W tej grupie znalazły się też matki, które nie ukończyły szkoły podstawowej, chociaż jest ich niewiele, tylko 1,5\% matek badanych studentów białoruskich. Ten typ wykształcenia nie wystąpił

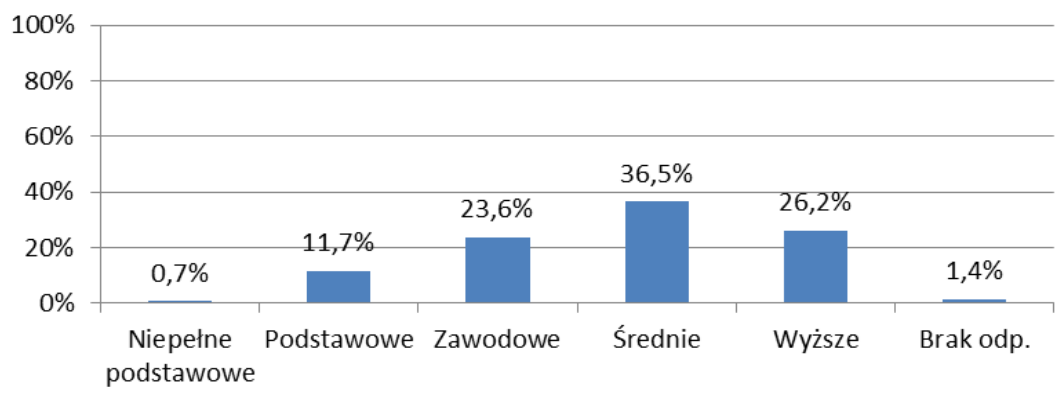

Ryc. 4. Wykształcenie matek badanych studentów polskich i białoruskich Źródło: badania własne 
wśród matek polskich studentów, dlatego na potrzeby dalszych analiz wpływu wykształcenia matek studentów na ich preferencje dla twórczych orientacji życiowych wykształcenie niepełne podstawowe zostanie połączone z podstawowym (rycina 4).

Wykształcenie ojców badanych studentów także jest zróżnicowane, zarówno wewnątrz grup narodowych, jak i pomiędzy nimi. Wynik testu chi-kwadrat, $\chi^{2}=29,5$ przy stopniach swobody $\mathrm{df}=4$ i poziomie istotności $\mathrm{p}=0,0000$, jest istotny statystycznie, co oznacza występowanie zależności między zmiennymi. Podobnie jak w poprzednim przypadku różnica dotyczy głównie proporcji między wykształceniem podstawowym i zawodowym (tabela 5).

Tabela 5. Wykształcenie ojców badanych studentów polskich i białoruskich

\begin{tabular}{|l|r|r|r|r|r|r|}
\hline \multirow{2}{*}{ Wykształcenie ojca } & \multicolumn{2}{|c|}{ Grupa polska } & \multicolumn{2}{c|}{ Grupa białoruska } & \multicolumn{2}{c|}{ Razem } \\
\cline { 2 - 8 } & \multicolumn{1}{c|}{$\mathrm{N}$} & \multicolumn{1}{c|}{$\%$} & $\mathrm{~N}$ & \multicolumn{1}{c|}{$\%$} & $\mathrm{~N}$ & \multicolumn{1}{c|}{$\%$} \\
\hline Niepełne podstawowe & 1 & 0,3 & 4 & 1,5 & 5 & 0,9 \\
\hline Podstawowe & 25 & 8,3 & 39 & 14,4 & 64 & 11,2 \\
\hline Zawodowe & 153 & 50,5 & 74 & 27,4 & 227 & 39,6 \\
\hline Średnie & 82 & 27,1 & 81 & 30,0 & 163 & 28,4 \\
\hline Wyższe & 39 & 12,9 & 51 & 18,9 & 90 & 15,7 \\
\hline Brak odp. & 3 & 1,0 & 21 & 7,8 & 24 & 4,2 \\
\hline Ogółem & 303 & 100,0 & 270 & 100,0 & 573 & 100,0 \\
\hline
\end{tabular}

Źródło: badania własne.

Wśród ojców polskich respondentów wyraźnie dominuje wykształcenie zasadnicze zawodowe, bez matury, legitymuje się nim połowa badanych, na drugim miejscu pod względem liczebności jest grupa ojców $\mathrm{z}$ wykształceniem średnim, 27,1\% z maturą, zaś na trzecim osoby z wykształceniem wyższym, których jest ponad połowę mniej $12,9 \%$. W stosunku do matek badanych studentów ojcowie mają niższe wykształcenie, jest wśród nich o 8,5\% mniej osób z wykształceniem średnim i o 14,2\% mniej osób z wykształceniem wyższym, natomiast więcej o 2,4\% z wykształceniem podstawowym i aż o 19,8\% więcej osób z wykształceniem zasadniczym zawodowym. Wśród białoruskich studentów przeważają ojcowie z wykształceniem średnim, jest ich więcej niż w polskiej grupie o 2,9 p.p., przewyższają oni także liczebnie polskich ojców pod względem wykształcenia wyższego o 6 p.p. i niemal o tyle samo pod względem wykształcenia podstawowego, natomiast jest w tej grupie znacznie mniej, o 23,1 p.p. w stosunku do grupy ojców polskich, osób z wykształceniem zasadniczym zawodowym. Relacje wykształcenia ojców białoruskich studentów z wykształceniem ich matek są podobne jak w grupie polskiej, z jedną tylko różnicą. Grupa ojców z wykształceniem podstawowym 
i niepełnym podstawowym jest o 3,7\% mniejsza niż grupa matek, podczas gdy wśród rodziców polskich studentów jest o 2,7\% więcej ojców z wykształceniem podstawowym (rycina 5).

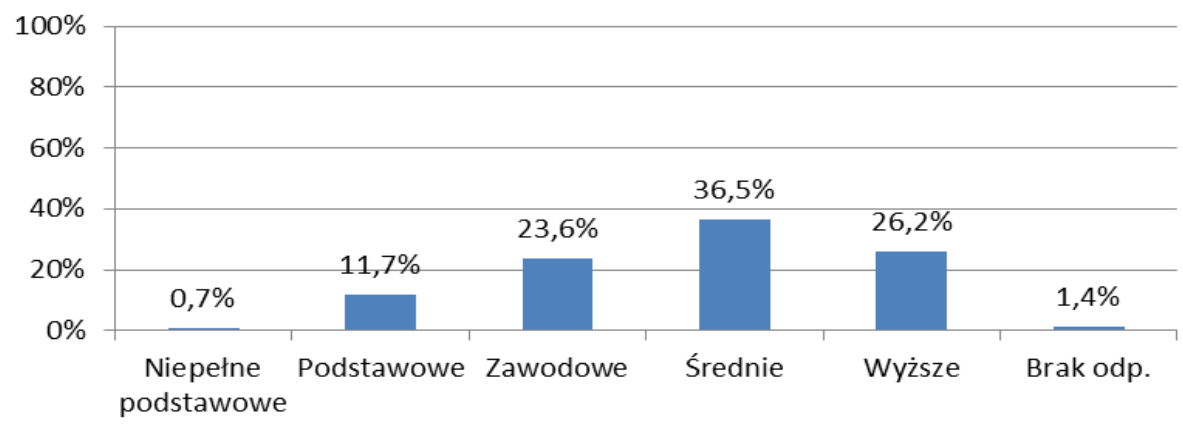

Ryc. 5. Wykształcenie ojców badanych studentów polskich i białoruskich Źródło: badania własne

Generalnie, matki są lepiej wykształcone niż ojcowie, w próbie polskiej 62,7\% matek badanych studentów legitymuje się świadectwem maturalnym lub dyplomem szkoły wyższej, w stosunku do 40\% ojców, niemal identycznie w próbie białoruskiej, w której 62,6\% matek ma wykształcenie średnie i wyższe, w stosunku do 48,9\% ojców białoruskich studentów. Niestety, w próbie białoruskiej było też sporo braków w danych dotyczących tej zmiennej. Na potrzeby analiz wpływu wykształcenia ojców na preferencje w zakresie twórczych orientacji życiowych, analogicznie jak dla matek, wykształcenie niepełne podstawowe zostało połączone z podstawowym.

Badana grupa jest zróżnicowana pod względem preferencji w zakresie orientacji życiowych w wymiarze twórcze-zachowawcze. Rozkład preferencji jest jednak podobny wewnątrz grup, jak i między grupami narodowymi. Zdecydowanie dominują tu preferencje dla twórczego ustosunkowania do życia, wyraża je trzy czwarte badanych. W próbie polskiej nieco więcej studentów niż w próbie białoruskiej, o 8 p.p., deklaruje poparcie dla zachowawczej orientacji i analogicznie, o tyle samo p.p. więcej jest białoruskich studentów, którzy preferują orientację twórczą (tabela 6).

Tabela 6. Preferencje badanych studentów w zakresie orientacji życiowych

\begin{tabular}{|l|c|c|c|c|c|c|}
\hline \multirow{2}{*}{ Typ preferencji } & \multicolumn{2}{|c|}{ Grupa polska } & \multicolumn{2}{c|}{ Grupa białoruska } & \multicolumn{2}{c|}{ Razem } \\
\cline { 2 - 7 } & $\mathrm{N}$ & $\%$ & $\mathrm{~N}$ & $\%$ & $\mathrm{~N}$ & $\%$ \\
\hline Preferencja dla ZOŻ & 87 & 28,7 & 56 & 20,7 & 143 & 25,0 \\
\hline Preferencja dla TOŻ & 216 & 71,3 & 214 & 79,3 & 430 & 75,0 \\
\hline Ogółem & 303 & 100,0 & 270 & 100,0 & 573 & 100,0 \\
\hline
\end{tabular}

Źródło: badania własne. 
Wynik testu chi-kwadrat, $\chi^{2}=4,8$ przy stopniach swobody $\mathrm{df}=1 \mathrm{i}$ poziomie istotności $\mathrm{p}=0,0277$, wskazuje istnienie zależności między analizowanymi zmiennymi. Jednak przyczyny tych różnic mogą być bardziej złożone niż wynikałoby to jedynie z przynależności narodowej badanych i kontekstu kulturowego. Grupy respondentów z obu krajów nie są bowiem jednorodne, jak wskazano w analizie, różnią się pod względem wieku, roku studiów, pochodzenia środowiskowego, wykształcenia rodziców (rycina 6).

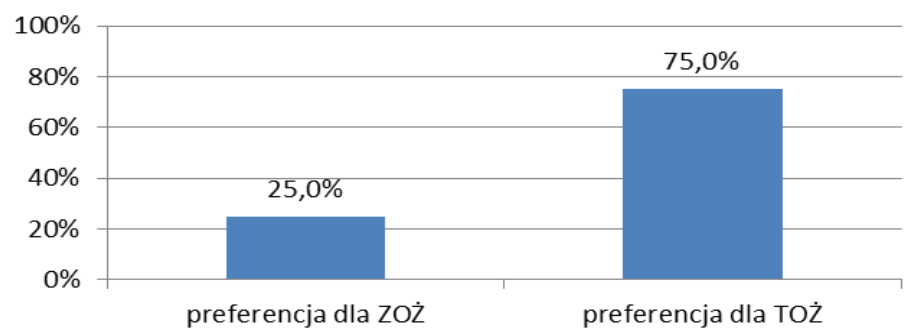

Ryc. 6. Preferencje badanych studentów polskich i białoruskich w zakresie orientacji życiowych na kontinuum twórcze-zachowawcze Źródło: badania własne

Interpretacja wyników wymaga uwzględnienia także siły preferencji badanych w zakresie obu typów orientacji. W Kwestionariuszu TOŻ, zawierającym czterostopniową skalę, badani mogli uzyskać od 0 do 144 punktów, wyniki mieszczące się w przedziale 73-144 punkty wskazują na preferencję dla twórczej orientacji, natomiast wyniki mieszczące się w przedziale 0-72 punkty wskazują na preferencję dla orientacji zachowawczej. Im więcej punktów uzyskuje badany, tym bardziej przesuwa się w kierunku lewego krańca kontinuum, czyli silnej preferencji dla TOŻ. Im mniejszą liczbę punktów zgromadzi dana osoba w badaniu, tym bardziej przesuwa się w kierunku prawego krańca kontinuum oznaczającego silną preferencję dla ZOŻ. Możliwe jest zatem pewne stopniowanie preferencji badanych w zakresie orientacji życiowych, bowiem badani, którzy uzyskali określoną liczbę punktów, mieszczącą się w jednym z dwóch przedziałów, różnią się między sobą stopniem akceptacji dla twierdzeń charakteryzujących oba typy ustosunkowania do życia (tabela 7). Okazało się, że studenci polscy i białoruscy deklarują akceptację twórczego ustosunkowania do życia na bardzo niskim poziomie, siła ich preferencji, poza kilkoma wyjątkami, jest słaba. Większość wyborów badanych w Skali TOŻ oscylowała zatem w zakresie kategorii pośrednich „a - trochę do mnie pasuje”, „b - trochę do mnie nie pasuje”. Nie zaobserwowano istotnych statystycznie zależności między analizowanymi zmiennymi, na co wskazuje wynik testu chi-kwadrat, $\chi^{2}=1,6$ przy stopniach swobody $d f=1$ i poziomie istotności $p=0,2059$ (rycina 7). 
Tabela 7. Natężenie preferencji twórczych orientacji życiowych (TOŻ) wśród badanych studentów polskich i białoruskich

\begin{tabular}{|l|c|r|r|r|r|r|}
\hline \multirow{2}{*}{ Preferencja dla TOŻ } & \multicolumn{2}{|c|}{ Grupa polska } & \multicolumn{2}{c|}{ Grupa białoruska } & \multicolumn{2}{c|}{ Razem } \\
\cline { 2 - 7 } & $\mathrm{N}$ & \multicolumn{1}{c|}{$\%$} & $\mathrm{~N}$ & $\%$ & $\mathrm{~N}$ & $\%$ \\
\hline Słaba & 209 & 96,8 & 211 & 98,6 & 420 & 97,7 \\
\hline Silna & 7 & 3,2 & 3 & 1,4 & 10 & 2,3 \\
\hline Ogółem & 216 & 100,0 & 214 & 100,0 & 430 & 100,0 \\
\hline
\end{tabular}

Źródło: badania własne.

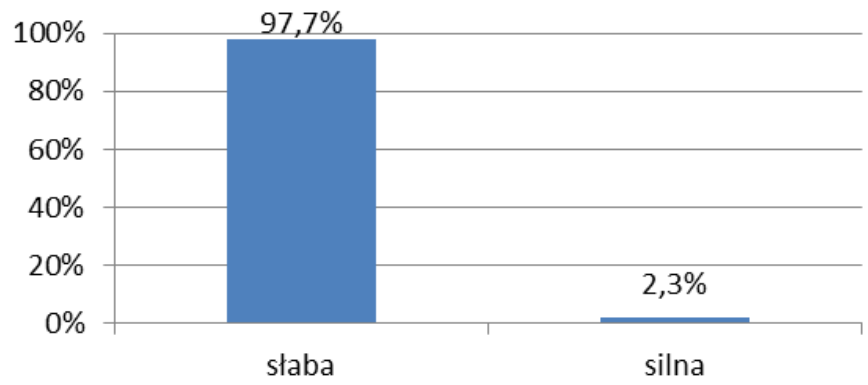

Ryc. 7. Siła preferencji twórczych orientacji życiowych w obu badanych grupach studentów Źródło: badania własne

Diagnoza preferencji w zakresie orientacji życiowych w wymiarze twórczezachowawcze objęła także analizę wpływu wybranych zmiennych socjodemograficznych na uzyskiwane wyniki w kwestionariuszu Skali TOŻ. Ze względu na liczebności i zróżnicowanie do analizy wybrano wiek respondentów w podziale na trzy grupy wiekowe wraz z analizą korelacyjną, pochodzenie środowiskowe, wykształcenie matki i ojca. Analizę porównawczą i korelacje przeprowadzono w ujęciu łącznym, dla wszystkich badanych oraz w podziale na studentów polskich i białoruskich. Weryfikację hipotez o istnieniu różnic wykonano testem Kruskala-Wallisa, zaś w przypadku wyników istotnych statystycznie przeprowadzono testy post-hoc Dunna. Do określenia korelacji między wiekiem a preferencjami orientacji życiowych wykorzystano współczynnik korelacji rang R Spearmana, natomiast istnienie związków pomiędzy typem preferencji a pozostałymi zmiennymi socjodemograficznymi sprawdzono za pomocą testu chi-kwadrat.

Grupy polska i białoruska różnią się wiekiem i o ile podział na kategorie sprawdza się dobrze dla całej próby, o tyle w przypadku analizy osobnej dla poszczególnych krajów napotykamy pewne trudności, które nakazują dużą ostrożność w formułowaniu wniosków. W grupie polskiej jest tylko 10 osób w wieku 17-19 lat, zaś w białoruskiej jedynie 10 osób w wieku 23 lata i więcej. Niezbędne jest zatem przeprowadzenie również analizy korelacji między zmiennymi, wiekiem badanych a ich preferencjami w zakresie orientacji życiowych twórcze-zachowawcze (tabela 8). 
Tabela 8. Preferencje orientacji życiowych w wymiarze twórcze-zachowawcze w kontekście wieku badanych studentów polskich i białoruskich

\begin{tabular}{|l|c|c|c|c|c|c|}
\hline \multirow{2}{*}{ Typ preferencji } & \multicolumn{2}{|c|}{$\begin{array}{c}\text { Studenci w wieku } \\
\text { 17-19 lat }\end{array}$} & \multicolumn{2}{c|}{$\begin{array}{c}\text { Studenci w wieku } \\
\text { 20-22 lata }\end{array}$} & \multicolumn{2}{c|}{$\begin{array}{c}\text { Studenci w wieku } \\
\text { 23 lata i więcej }\end{array}$} \\
\cline { 2 - 7 } & $\mathrm{N}$ & $\%$ & $\mathrm{~N}$ & $\%$ & $\mathrm{~N}$ & $\%$ \\
\hline Preferencja dla ZOŻ & 25 & 17,0 & 64 & 27,9 & 54 & 27,4 \\
\hline Preferencja dla TOŻ & 122 & 83,0 & 165 & 72,1 & 143 & 72,6 \\
\hline Ogółem & 147 & 100,0 & 229 & 100,0 & 197 & 100,0 \\
\hline
\end{tabular}

Źródło: badania własne.

Wynik testu chi-kwadrat, $\chi^{2}=6,7$ przy stopniach swobody $\mathrm{df}=2 \mathrm{i}$ poziomie istotności $\mathrm{p}=0,0353$, wskazuje na istotne zależności między zmiennymi, młodsi respondenci częściej preferują twórcze orientacje życiowe, chociaż są to deklaracje na niskim poziomie akceptacji, gdyż takie zdecydowanie dominują w całej badanej próbie. Analiza testami wielokrotnych porównań Kruskala-Wallisa i Dunna ujawnia istnienie różnic jedynie pomiędzy grupą najstarszą - 23 lata i więcej a najmłodszą - 17-19 lat w odniesieniu do podskali TOŻ Nowe sytuacje (Ns), TOŻ Elastyczność, giętkość, oryginalność myślenia (E), TOŻ Twórczość jako wartość (Tw) ${ }^{4}$. Zależności między wiekiem badanych studentów polskich i białoruskich a ich preferencjami w zakresie orientacji życiowych w wymiarze twórcze-zachowawcze, w poszczególnych podskalach przedstawiono za pomocą współczynnika rang Spearmana (tabela 9).

Tabela 9. Korelacje rang Spearmana między wiekiem badanych a ich preferencjami w zakresie orientacji życiowych w wymiarze twórcze-zachowawcze

\begin{tabular}{|l|c|c|c|c|}
\hline \multicolumn{1}{|c|}{ Para zmiennych } & $\mathrm{N}$ & R Spearman & $\mathrm{t}(\mathrm{N}-2)$ & $\mathrm{p}$ \\
\hline TOŻ Ns \& Wiek & 573 & $-0,08$ & $-1,94$ & 0,0534 \\
\hline TOŻ Nw \& Wiek & 573 & $-0,03$ & $-0,65$ & 0,5172 \\
\hline TOŻ E \& Wiek & 573 & $-0,10$ & $-2,32$ & 0,0208 \\
\hline TOŻ Tw \& Wiek & 573 & $-0,12$ & $-2,88$ & 0,0041 \\
\hline Preferencje TOŻ \& Wiek & 573 & $-0,11$ & $-2,53$ & 0,0116 \\
\hline ZOŻ Ns \& Wiek & 573 & 0,12 & 2,87 & 0,0042 \\
\hline ZOŻ Nw \& Wiek & 573 & $-0,07$ & $-1,73$ & 0,0834 \\
\hline ZOŻ E \& Wiek & 573 & 0,10 & 2,45 & 0,0147 \\
\hline ZOŻ Tw \& Wiek & 573 & 0,24 & 6,00 & 0,0000 \\
\hline Preferencje ZOŻ \& Wiek & 573 & 0,14 & 3,27 & 0,0012 \\
\hline Suma TOŻ \& Wiek & 573 & 0,02 & 0,42 & 0,6775 \\
\hline
\end{tabular}

Uwaga: podświetlone wartości są istotne statystycznie.

Źródło: badania własne.

${ }^{4}$ Nie zamieszczam tabel z wartościami statystycznymi, jako zbyt obszerny materiał do prezentacji w artykule. 
Korelacje między wskazanymi w tabeli parami zmiennych są co prawda istotne statystycznie, ale są też bardzo słabe. Podobnie jak w przypadku podskal twórczych preferencji wyglądają relacje między wiekiem badanych a wynikami w poszczególnych podskalach zachowawczych preferencji. Istotne, choć także bardzo słabe korelacje zaobserwowano między wiekiem studentów polskich i białoruskich a ich akceptacją twierdzeń w podskalach: ZOŻ Nowe sytuacje (Ns), ZOŻ Elastyczność, giętkość, oryginalność myślenia (E), ZOŻ Twórczość jako wartość (Tw). W grupie polskich studentów porównania wielokrotne, dwustronne między preferencjami orientacji życiowych w wymiarze twórcze-zachowawcze, w poszczególnych podskalach i w całości a wiekiem badanych nie ujawniły istotnych różnic. Wynika to zapewne z bardzo małej liczebności próby w najniższym przedziale wiekowym 17-19 lat, wśród polskich studentów było jedynie 10 takich osób i choć test Kruskala-Wallisa był istotny statystycznie, to już test post-hoc Dunna nie potwierdził hipotezy o istnieniu różnic między zmiennymi. Układ preferencji w zakresie twórczych orientacji życiowych w grupie polskich studentów w różnym wieku oddaje ich specyfikę $\mathrm{w}$ całej badanej próbie. Preferencje dla określonego typu orientacji życiowych nie są zależne od wieku badanych. Analizy korelacji nie ujawniły żadnych związków między tymi zmiennymi, ani w grupie polskich, ani w grupie białoruskich studentów. W żadnej z czterech podskal obejmujących „Nowe sytuacje”, „Nowe wytwory”, „Elastyczność, giętkość, oryginalność myślenia” i „Twórczość jako wartość", składających się na preferencje dla twórczych orientacji życiowych nie zaobserwowano zależności od wieku badanych.

W toku porównań wielokrotnych i analiz korelacyjnych nie stwierdzono zależności między pochodzeniem środowiskowym badanych studentów polskich i białoruskich, analizowanych łącznie i osobno, a uogólnionymi preferencjami w zakresie twórczych orientacji życiowych, preferencjami badanych w poszczególnych podskalach, a więc między środowiskiem, z którego pochodzi badany, a jego preferencjami twórczymi, czyli wynikami w podskali twórcze orientacje i preferencjami w podskali zachowawcze orientacje. Nie zaobserwowano także żadnych związków statystycznych między preferencjami badanych studentów, polskich i białoruskich łącznie, w poszczególnych podskalach, twórczej i zachowawczej, a wykształceniem ich matek. Nieco odmienną sytuację mamy jednak w przypadku grupy polskich studentów, bowiem analizy testem nieparametrycznym istotności różnic ujawniły występowanie pewnych korelacji między analizowanymi zmiennymi (tabela 10).

Wynik testu chi-kwadrat, $\chi^{2}=10,6$ przy stopniach swobody $\mathrm{df}=3 \mathrm{i}$ poziomie istotności $\mathrm{p}=0,0139$, jest istotny statystycznie, co wskazuje na to, że typ ustosunkowania do życia badanych studentów polskich zależy od wykształcenia ich matek. Młodzi ludzie, których matki mają wykształcenie średnie i wyższe, częściej niż ci, których matki mają niskie wykształcenie, preferują twórczą orientację życiową. Wykształcenie średnie i wyższe matki sprzyja twórczemu ustosunkowaniu do życia dziecka. Natomiast w grupie białoruskiej młodzieży akademickiej nie zaobserwo- 
Tabela 10. Typ preferencji w zakresie orientacji życiowej a wykształcenie matek badanych studentów polskich

\begin{tabular}{|l|c|c|c|c|c|c|c|c|}
\hline \multirow{2}{*}{ Typ preferencji } & \multicolumn{2}{|c|}{ Podstawowe } & \multicolumn{2}{c|}{ Zawodowe } & \multicolumn{2}{c|}{ Średnie } & \multicolumn{2}{c|}{ Wyższe } \\
\cline { 2 - 9 } & $\mathrm{N}$ & $\%$ & $\mathrm{~N}$ & $\%$ & $\mathrm{~N}$ & $\%$ & $\mathrm{~N}$ & $\%$ \\
\hline $\begin{array}{l}\text { Preferencja dla } \\
\text { ZOŻ }\end{array}$ & 9 & 50,0 & 33 & 35,5 & 29 & 26,9 & 15 & 18,3 \\
\hline $\begin{array}{l}\text { Preferencja dla } \\
\text { TOŻ }\end{array}$ & 9 & 50,0 & 60 & 64,5 & 79 & 73,1 & 67 & 81,7 \\
\hline Ogółem & 18 & 100,0 & 93 & 100,0 & 108 & 100,0 & 82 & 100,0 \\
\hline
\end{tabular}

Źródło: badania własne.

wano takiej zależności, wykształcenie matek badanych studentów nie ma związku $\mathrm{z}$ ich preferencjami w zakresie twórczych orientacji życiowych. W toku porównań wielokrotnych i analiz korelacyjnych nie stwierdzono również żadnych zależności między wykształceniem ojców badanych studentów polskich i białoruskich a uogólnionymi preferencjami w zakresie twórczych orientacji życiowych. Nie zaobserwowano także istotnych różnic w wyborach dokonywanych przez badanych studentów w poszczególnych podskalach, twórczej i zachowawczej, zależnie od wykształcenia ich ojców.

\section{Konkluzje}

Badania nad twórczymi orientacjami życiowymi, które realizuję od kilkunastu lat, umożliwiają śledzenie specyfiki preferencji w tym zakresie, szczególnie wśród młodzieży akademickiej, ponieważ jest to grupa dominująca w eksploracjach tego obszaru. Prezentowane w niniejszym artykule wyniki ujawniają tendencję do preferowania przez młodzież twórczego ustosunkowania do życia, ale na niskim poziomie akceptacji twierdzeń opisujących ten typ orientacji. Można zatem stwierdzić, że znakomita większość badanych sytuuje się tylko nieznacznie bliżej krańca twórczych orientacji niż zachowawczych. Narodowość nie różnicuje tutaj próby badanej, bowiem sytuacja taka jest obserwowana zarówno w grupie polskich, jak i białoruskich studentów. Gdyby wprowadzić do analizy orientację ambiwalentną, tak jak było to $\mathrm{w}$ pierwszych badaniach nad twórczymi orientacjami życiowymi, zapewne część badanych można byłoby określić jako osoby niezdecydowane, co do swojego ustosunkowania do życia. Wskazuje bowiem na to niski poziom akceptacji twórczych orientacji. Przy tak słabej preferencji dla nich trudno prognozować także dynamikę badanego zjawiska. W toku nabywania nowych doświadczeń życiowych, wchodzenia $w$ inne niż akademickie środowiska, podejmowania nowych ról społecznych, preferencje te mogą ulegać zmianom i przesuwać się bliżej jednego z dwóch krańców kontinuum. Niski poziom akceptacji twórczego ustosunkowania do życia, przynajmniej w części przypadków, może prowadzić do stosunkowo 
łatwego porzucania przekonań związanych z kreatywną postawą na rzecz zachowawczej orientacji. Taki stan rzeczy może mieć też niekorzystne konsekwencje dla poczucia koherencji badanych, które w salutogenetycznym modelu zdrowia Aarona Antonovsky'ego (2005), sprzyja poczuciu zdrowia i dobrostanowi człowieka.

W wyniku analiz porównawczych i korelacyjnych nie stwierdzono zależności między preferencjami twórczych orientacji życiowych badanych studentów polskich i białoruskich a wybranymi zmiennymi socjodemograficznymi. Grupy te różnią się natomiast istotnie statystycznie pod względem wieku, roczników i pochodzenia środowiskowego. Nie zaobserwowano natomiast zależności między preferencjami badanych dla twórczych orientacji życiowych a ich pochodzeniem środowiskowym czy wykształceniem ich ojców. Zdiagnozowano jedynie niezbyt silne korelacje zmiennej zależnej $\mathrm{z}$ wiekiem badanych, ale duże dysproporcje $\mathrm{w}$ liczebności grup wiekowych nie pozwalają na formułowanie w tym względzie jakichś szerszych wniosków. Pewne różnice między próbą polską i białoruską stwierdzono w odniesieniu do wykształcenia matek badanych studentów. W grupie polskiej średnie i wyższe wykształcenie matek badanych studentów sprzyja preferowaniu przez nich twórczego stosunku do życia. Potwierdza to obserwowane $\mathrm{w}$ wielu badaniach znaczenie statusu edukacyjnego matek w społecznym funkcjonowaniu ich dzieci.

\section{Bibliografia}

Antonovsky A. (2005) Rozwikłanie tajemnicy zdrowia. Jak radzić sobie ze stresem i nie zachorować, tłum. H. Grzegołowska-Klarkowska, Warszawa, Instytut Psychiatrii i Neurologii.

Craft A. (2001) Little c Creativity in: Creativity in Education, A. Craft, B. Jeffrey, M. Leibling (eds.) London-New York, Continuum, s. 45-61.

Csikszentmihalyi M. (1991) Flow. The Psychology of Optimal Experience, New York, Harper Perennial.

Cudowska A. (1997) Orientacje życiowe współczesnych studentów, Białystok, Trans Humana.

Cudowska A. (2004) Kształtowanie twórczych orientacji życiowych w procesie edukacji, Białystok, Trans Humana.

Cudowska A. (2014) Twórcze orientacje życiowe w dialogu edukacyjnym. Studium teoretyczno-empiryczne, Białystok, Trans Humana.

Cudowska A. (2017) Twórcze orientacje życiowe. Zdrowie i dobrostan, Białystok, Wydawnictwo Uniwersytetu w Białymstoku. 
Czerepaniak-Walczak M. (2006) Pedagogika emancypacyjna. Rozwój świadomości krytycznej człowieka, Gdańsk, Gdańskie Wydawnictwo Psychologiczne.

Fromm E. (1959) The Creative Attitude w: Creativity and its Cultivation. Adresses Presented at The Interdisciplinary Symposia on Creativity, H. H. Anderson (ed.), New York, Harper and Row, s. 44-54.

Husserl E. (1967) Idee czystej fenomenologii i fenomenologicznej filozofii, t. 1, tłum. D. Gierulanka, wstęp R. Ingarden, Warszawa, PWN.

Korniłowicz K. (1976) Pomoc społeczno-kulturalna dla młodzieży pracującej i dorosłych. Wybór pism, wstęp, wybór i opracowanie O. Czerniawska, Wrocław, Ossolineum.

Kozielecki J. (1987) Koncepcja transgresyjna człowieka, Warszawa, PWN.

Kozielecki J. (1997) Transgresja i kultura, Warszawa, Wydawnictwo Akademickie „Żak".

Kozielecki J. (2001) Psychotransgresjonizm. Nowy kierunek psychologii, Warszawa, Wydawnictwo Akademickie „Żak”.

Kozielecki J. (2004) Społeczeństwo transgresyjne. Szansa i ryzyko, Warszawa, Wydawnictwo Akademickie „Żak”.

Maslow A. H. (1959) Creativity in Self-actualizing People w: Creativity and its Cultivation. Adresses Presented at The Interdisciplinary Symposia on Creativity, H. H. Anderson (ed.), New York, Harper and Row, s. 83-95.

May R. J. (1959) The Nature of Creativity in: Creativity and its Cultivation. Adresses Presented at The Interdisciplinary Symposia on Creativity, H. H. Anderson (ed.), New York, Harper and Row, s. 55-68.

Miles M. B., Huberman A. M. (2000) Analiza danych jakościowych, tłum. S. Zabielski, Białystok, Trans Humana.

Modrzejewska-Świgulska M. (2013) Twórczość codzienna jako zasób wspierajacy dobrostan ludzi w: Zasoby twórcze człowieka. Wprowadzenie do pedagogiki pozytywnej, K. J. Szmidt, M. Modrzejewska-Świgulska (red.), Łódź, Wydawnictwo Uniwersytetu Łódzkiego, s. 83-106.

Perls F. S. (1969) Gestalt Therapy Verbatim, New York, Real People Press.

Radlińska H. (1979) Oświata i kultura wsi polskiej: wybór pism, Warszawa, Ludowa Spółdzielnia Wydawnicza. 
Richards R. (1999) Everyday Creativity w: Encyclopedia of Creativity, M. A. Runco, S. R. Pritzker (eds.), San Diego, Academic Press, s. 683-689.

Richards R. (2007) Everyday Creativity: Our Hidden Potential w: Everyday Creativity and New Views of Human Nature. Psychological, Social, and Spiritual Perspectives, R. Richards (ed.), Washington D.C., American Psychological Association, s. 25-53.

Rogers C. R. (1954) Towards a Theory of Creativity, "ETC: A Review of General Semantics", no. 11, s. 249-260.

Runco M. A. (2005) Creativity Giftedness in: Conceptions of Giftedness, R. J. Sternberg, J. Davidson (eds.), Cambridge, University Press, s. 295-311.

Seligman M. E. P. (2005) Prawdziwe szczęście. Psychologia pozytywna a urzeczywistnianie naszych możliwości trwałego spełnienia, tłum. A. Jankowski, Poznań, Wydawnictwo Media Rodzina.

Szmidt K. J. (2013) Pedagogika twórczości, Sopot, Gdańskie Wydawnictwo Psychologiczne.

Szmidt K. J. (2013a) Pedagogika pozytywna: twórczość - zdolność - mądrość zespolone w: Zasoby twórcze człowieka. Wprowadzenie do pedagogiki pozytywnej, K. J. Szmidt, M. Modrzejewska-Świgulska (red.), Łódź, Wydawnictwo Uniwersytetu Łódzkiego, s. $13-40$.

Szulakiewicz M. (2003) Dialog jako podstawa metafizyki. Od metafizyki fundamentu do metafizyki orientacji, „Filozofia Dialogu”, t. 1, Poznań, Wydział Teologiczny UAM, s. 11-27.

Tischner J. (1993) Myślenie według wartości, Kraków, Wydawnictwo Znak.

Tischner J. (2000) Świat ludzkiej nadziei, Kraków, Wydawnictwo Znak.

Zinker J. (1977) The Creative Process in Gestalt Therapy, New York, Vintage Books. 